\title{
Wonder, Sorcery, and Technology: Contribute to the History of Medieval Robotics
}

\author{
Nadia Ambrosetti \\ Dipartimento di Informatica e Comunicazione, Università degli Studi di Milano \\ Via Comelico 39/41, 20135 Milano, Italy \\ nadia.ambrosetti@unimi.it
}

\begin{abstract}
The paper considers some Medieval sources about imagined or actually studied automata, to make a contribution to the reconstruction of the cultural landscape of a period that, from the technological point of view, is commonly regarded as less interesting than others. It will be shown that the idea of an automatic device or system, capable of performing not necessarily simple tasks, of measuring its own state and of taking action based on it, was well established in the Medieval mind, even though sometimes connected with magic.
\end{abstract}

Keywords: automata, design, sorcery, science, technology, feed-back control, history, magic, robot, robotics.

\section{Introduction}

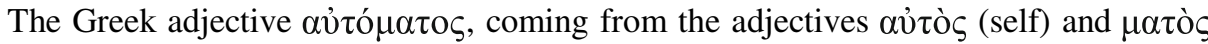
(having in mind, acting), was at first used to refer to any event, that happened spontaneously, without external intervention; later its use was extended to those mechanical devices, which perform, after a user's input, a finite number of default actions, typically, but not necessarily in a periodic sequence. Such automata were, during the Hellenism, also equipped with mechanisms for controlling their state and were so capable of taking action in dependence on the state itself (a first and essential mechanism for feedback). The purpose they were built for, was essentially playful: they were made to arouse the spectators' wonder $(\theta \alpha \tilde{v} \mu \alpha)$ and therefore their admiration not only for the engineer's skills, but also for the monarch, who had sponsored his designs and works. Often, these designers managed to surprise their audience through the implementation of devices activated by an input that doesn't appear to involve the produced effect: the typical example is the mechanism that opens the doors of a temple after the lighting of a ritual brazier. We rarely find examples of devices which also can have a practical use (such as a purifying water dispenser, or a pump to extinguish fires).

The most important source for this study are the works by Hero of Alexandria $\left(1^{\text {st }}\right.$

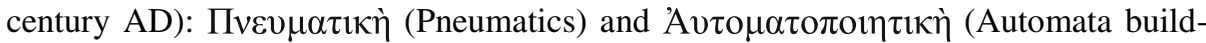
ing); these works came to us almost complete and they let us understand much of ancient engineering applied to automata. This fortunate tradition demonstrates that such works passed from Alexandria into the Romans' hands at first, then to the Byzantines and Arabs; during the Dark and Middle Ages they were read, understood, 
and copied, so that today, dispersed in many European libraries, we have respectively more than 100 copies in Greek language, and 13 translated into Latin [1]. Another well-known author of a treatise about Pneumatics is also Philo of Byzantium [2-3]: his work, though less widespread than Hero's, was, however, read and studied during the Middle Ages and today we have 15 manuscripts of Latin translations, mostly entitled De spiritualibus ingeniis (About devices dealing with fluids).

\section{The "Thauma Connection": From Alexandria to Baghdad, and Byzantium}

When these works came into the hands of Arabic and Byzantine scholars, they were not only subject to a thorough theoretical study, but they also brought to the actual implementation of devices. While in the Byzantine empire no translation of these texts was required, in the $9^{\text {th }}$ century, Qusta ibn Luqa, author of many translations of scientific works from Greek into Arabic, provided Arabic scholars with a version of Hero's Mechanics.

The social structure of the Byzantine and the Arabic empires was fundamentally identical to the Alexandrian one: the king (emperor or caliph) was the undisputed arbiter of cultural life; for his impressive palace, wonderful automata were constructed for the double purpose of amusing the king and his court, and of arousing the admiration of the audience, mainly ambassadors of foreign peoples.

\subsection{Arabic World}

In the Arabic world, the most famous scholars in this field were the brothers Banu Musa, who lived in the $9^{\text {th }}$ century in Baghdad, and al-Jazari, who flourished between the $12^{\text {th }}$ and $13^{\text {th }}$ centuries [4-5]. Their works titles are all connected with the idea of surprising the audience, and their actual achievements were exactly in that direction, although by different paths: they tried to reproduce scenes of wildlife (birds singing on a tree), or men and women performing some actions (e.g., an orchestra of musicians playing a song on a boat floating in a pool of the royal garden; a drink-serving waitress). Some of these automata had however a practical purpose, such as a medical equipment, like the device for measuring the amount of blood drawn with the phlebotomy, or liturgical objects, such as a peacock-shaped basin for ritual ablutions.

\subsection{Byzantine Empire}

At the magnificent court of Byzantium, the natural heir of Hellenistic tradition, but also of the splendour of the Eastern world, automatic devices seem to have been exclusively used in the imperial Great Palace, in the Magnaura. Interestingly, in this case, the sources are not technical and no name of architect or engineer, that made automata in Byzantium, was handed down.

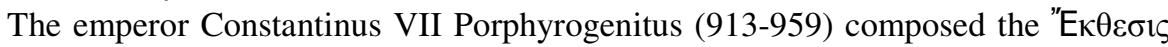

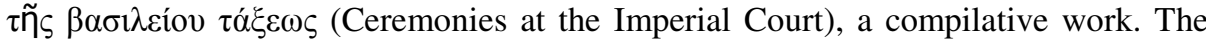
main content is a detailed description of the ceremonies from the court's point of view; in II,15, he relates what usually happened during a typical audience granted by the emperor: after the ritual bowing, the postulant heard a roar coming from the lions 
on either side of the throne, while birds, resting on the trees that surrounded the throne, began to sing harmoniously. Subsequently, the lions, in perfect synchrony with the various moments of the ceremony, departed from their starting position and then returned back to it; both lions and birds gave up singing at the end of the ceremony [6-7].

A very similar ritual is also described by the bishop Liutprand of Cremona (920972), in his Antapodosis, a report about his stay at the court of Byzantium as an ambassador of Berengarius II (900-966), who was eager to be accredited as king of Italy by the emperor of the Eastern Roman Empire; Liutprand was formally received by Constantinus Porphyrogenitus, in 949, and stayed for some time in the city, taking part in court ceremonies [8-9].

The presence of a tree near a king's throne [10] dates back to the Sumeric epic of Gilgamesh; a golden plate tree and a golden vine are also cited in Herodotus' Histories (VII, 27), as a gift to the Persian emperor Darius by the king of Lydia, Pythius, grandson of the renown Croesus [11-12]. Singing birds are likely to have been inspired by Hero's and Philo's Pneumatics (respectively, I, 4; I, 5; I, 16; and 61, for instance), exactly as it had happened in the Arabic world, but, given such lack of technical Byzantine sources, one could also suppose that the Byzantine engineers were inspired by Arabic designs or models possibly seen in Baghdad. The reference to such a device by the Sicilian poet Ibn Hamdis, who lived during the $11^{\text {th }}$ century, could support the hypothesis of the spreading of such automaton design [13].

Concerning the lions, an iconographic source for the Byzantine engineers could have been the throne of Solomon, as described in the Bible (Kings, I, x, 18-20), though no reference is here made to any motion.

These automata show perfectly how the intellectual resources of the Byzantines (in this case, their competence in the fields of mechanical engineering) could be used as instrumentum regni, and they also demonstrate the effort that was made both in the imitation of nature, and in showing the emperor as a God's epiphany.

Automata descriptions within the Byzantine Empire are also present in many literary works written in order to entertain the audience: romances, and allegorical poems [14].

\section{Dark and Middle Ages}

After the great season of Hellenistic engineering and during all the early medieval centuries in the Eastern Roman Empire or in the territories under Arabic domination, the sources related to automata decrease dramatically and are limited in Europe to secondary references, and to romances. No designs or technical descriptions are available, at least until the $13^{\text {th }}$ century.

\subsection{Dark Ages}

Anyway, secondary sources can testify the existence of mechanical precision devices, demonstrating that even in Roman-barbarian kingdoms the technical skills required for such objects were not completely lost.

For instance, in Cassiodorus' Variae, the official correspondence of the Ostrogothic court in Ravenna, a letter $(\mathrm{XLV}, 6)$ addressed to the philosopher Boethius is preserved; Theodoric says that the Burgundian king has repeatedly asked him for a 
water clock and for craftsmen (probably as maintenance men); he comments the episode with revealing words: the reason why the Burgundian king insisted so much, is that he considers as a "miraculum" (wonder) an object that for Theodoric is instead "cottidianum" (daily) [15].

Although we can suppose that Theodoric overemphasized his acquaintance with these devices, it is clear that at the beginning of the $7^{\text {th }}$ century in Europe there were still craftsmen capable of building a water clock.

\subsection{Middle Ages}

Another important secondary source consists in romances [16]: whether they belong to the Matter of Britain (King Arthur's stories) or of France (Charles the Great's stories), or of Rome (the main character is taken from ancient history, such as Julius Caesar or Alexander the Great), references to automata are frequent; they are primarily used as guardians of a strategic place (a tomb, a bridge, a cave, or a castle) and their makers are usually magicians, not technicians.

The reason is easily explained: all mechanical arts were in no esteem throughout the Middle Ages to the point that, for a cultured man, technical practice was considered morally, religiously, and socially dishonorable [17]. On the contrary, knowledge and practice of magic were reserved for a selected group of people, who had chosen to engage in "religiously illicit pursuits, illegitimate knowledge, and trafficking with the Devil" [18]; by attributing the construction of automata to magicians, any moral conflict was avoided.

Even the legends about the French monk Gerbert d'Aurillac (946-1003), later Pope Sylvester II, and the Dominican philosopher Albertus Magnus (1206-1280) as automata builders, reveal an explicit moral intent: both episodes end with the destruction of the automaton (Albertus' talking head would have been broken by one of his students, St. Thomas Aquinas), which is moreover impossible to restore.

\subsubsection{The Great Sorcerer Gerbert d'Aurillac?}

In Gerbert's biography by William of Malmesbury (1080/1095-1143), an interesting event is reported [19-20]. During his stay in Rome, the future pope had decided (by sheer greed) to rescue Octavian's treasure, buried, according to a legend, in a cave beneath the Roman Forum; the cave entrance was indicated by a statue. Many others had unsuccessfully tried to find the entrance, being less artful than him: he marked the place, where the shadow of a statue's finger fell at noon-day; at night he made the earth open by means of his magical arts and, attended by a servant with a lantern, he entered a beautiful golden palace, where they found a court of golden automata. The light source was a small carbuncle of the first quality, standing on a base. At the opposite corner of the room, stood a young archer, holding a bow and an arrow. Gerbert and his servant soon noticed that, if they tried to take anything, all these automata appeared to rush forward to attack them. So Gerbert guessed what would be the consequences of such an attempt, and decided to give up, but his servant, unable to resist, decided to steal a superb knife. Immediately, the automata cried loudly and began moving, and the archer shot the carbuncle with his arrow, so that all was in darkness; Gerbert ordered his servant to drop the knife, otherwise their lives would have been in danger. He obeyed, and they left the palace, though without any treasure. 
The story is very interesting from several points of view.

First of all, the palace designer had planned the system in order to kill any thieves or at least to give them a moral lesson, not to impress them with the automata's capabilities. We have the description of an actual distributed system made up of automata: they are all running the same task (stop the intruders, if they are stealing something). The actions performed by the automata are not periodical: they begin and end depending on values measured by "sensors". Nothing is said about how the system reverts to its initial state after the departure of the intruders.

Then, in Hero's Pneumatics (I, 41), an automaton composed by two figures, entitled Hercules and the Snake, is described: when a user lifts an apple (placed between the statue of the archer Hercules and the tree the snake is wrapped around) Hercules shoots with an arrow the snake, which in the meanwhile begins to hiss. Its operation is relatively simple: the base of the group is divided horizontally into two parts (the top compartment is full of water), connected by a drain hole, where a cork is set. By raising the apple, a double synchronous effect is produced:

1. a chain, connected to the apple, pulls the cork from the hole, causing the gurgling through the various ducts that is similar to a snake hiss;

2. a second chain, also connected to the apple, acts on the figure of Hercules, making him stretch and release the string of his bow.

In addition, in a French romance, whose first written version dates to the middle of the $12^{\text {th }}$ century, entitled Le pèlerinage de Charlemagne (Charles the Great's Pilgrimage), the setting of the emperor's main adventure is the vaulted and circular palace of Hugon, emperor of Constantinople, where Charles and his 12 peers are housed as guests in a beautiful bed-chamber, full of precious decorations and refined objects. The light source is a carbuncle, set on a pillar [21]. The front of the palace is decorated with the statues of two smiling young men, holding ivory horns. Whenever a wind comes up, these images blow their horns, producing a loud clear sound, and immediately the palace begins rotating. A carbuncle and a moving room appear also in the $14^{\text {th }}$-century allegorical poem titled $\Sigma$ Meliteniotes [22]. Here we also find an abridged version of a lapidary, a book where stones are put in relation with moral qualities: the carbuncle is a symbol for temperance, a cardinal virtue, related to self-control.

Last, but not least, remark: Gerbert is told to have designed and built a water organ, during his stay in Reims; his treatise on the subject has been recently studied [23].

Even taking into consideration that this is a legendary episode, one cannot but be struck by the strong similarity between this system and the Heronian automaton, which may have been the remote source of the story, though it was considered neither in the Arabic written tradition nor in the Byzantine implementations.

It is therefore reasonable to make two assumptions, not mutually exclusive:

1. This knowledge was transmitted within the workshops by the masters to their apprentices from the Antiquity to the Middle Ages with or without Arabic contribution; it is unfortunately very hard to prove such an assumption, due to the lack of sources.

2. A Latin cultured tradition, mostly separated from the Arabic one, existed, and flourished, probably in the monasteries; this second assumption could be easier to prove, by means of a census of Latin manuscripts on the subject. 


\subsubsection{Looking for Pneumatics' Medieval Latin Tradition}

Despite the wide diffusion of Arabic culture and technology, that had accompanied the territorial expansion of the $7^{\text {th }}-15^{\text {th }}$ centuries, at the time neither the Latin versions of Arabic engineers' masterpieces, nor information in this regard are available, since the lists of the translations carried out in Europe don't include these works. We may assume that the oldest (so far as it is known at the moment) Latin translation of Philo's Pneumatics (Cambridge, Pembroke College, 169) has been made from an Arabic translation: its incipit "In nomine Dei pii <et> misericordis..." is common to other Latin translations of Arabic scientific works (e.g., Robert of Chester's version of al-Khwarizmi's al-jabr w'al-muqabalah, or Iohannes Hispalensis' De scientia astrolabii) [24-25].

It is equally unlikely that Byzantine technical works existed, since in European libraries no Greek manuscripts are housed dating before the $15^{\text {th }}$ century. Even the oldest copy of Hero's Pneumatics (Venezia, Biblioteca Marciana, gr. 516) dates back to the $13^{\text {th }}$ century, but it was brought to Italy from Byzantium by Cardinal Bessarion during the $15^{\text {th }}$ century.

Another part of Europe where an intense activity of translation took place, was the Norman Sicily [26]: Greek, and Arabic works were translated into Latin [27]. One of the most renowned translators in the $12^{\text {th }}$ century was the archdeacon of Catania, Henricus Aristippus, whose origins and life are still largely unknown. He translated from Greek into Latin Diogenes Laertius' works, Ptolemy's Almagest, Plato's Meno and Phaedo, Aristotle's Meteorologica. In his preface to the translation of the Phaedo, he addresses to an Englishman who was to return home from Sicily, using the following words: " [...] Habes Heroni philosophi Mechanica pre manibus, qui tam subtiliter de inani disputat [...]" (you have in your hands the Mechanics by Hero, who so subtly deals with the void). These words led Rose and Birkenmajer [28-29] to believe that it was the Pneumatics, since in the Mechanics Hero doesn't speak of void; Haskins [30-32] refused such an inference, because the content of Mechanics is known only from Arabic translations, possibly incomplete; moreover, Haskins rejected the subsequent inference by the above mentioned scholars as a risky assumption: according to them, Henricus was referring to his own Latin translation, since other translations of his are quoted in the passage.

Birkenmajer [33] goes further than Rose, stating that he had found evidence of a copy of this translation in the Biblionomia (the library catalogue of the French philosopher and poet Richard de Fournival, living in the $13^{\text {th }}$ century), where the Pneumatics would be referred to as Excerpta de libro Heronis de specialibus ingeniis (excerpts from Hero's book about special devices); "specialibus" is probably a wrong transcription of "spiritualibus" (concerning with void), due to the fact that the shortening of the two words is identical. Unfortunately, though the library is now part of the Bibliothèque Nationale de France, no evidence of the manuscript is now available, and even the assumptions that it could be Philo's instead of Hero's Pneumatics, or a Latin translation of an Arabic compilation from Banu Musa's work, can be neither validated nor rejected [34].

Birkenmajer also argues that, in the $13^{\text {th }}$ century, the Flemish Dominican William of Moerbecke would have translated, among many other works, Hero's Pneumatics into Latin; his proof is based on the presence of a treatise entitled De aquarum conductibus et ingeniis erigendis in a list of works, owned by St.Thomas, actually 
translated by the Flemish scholar [29]. Although the evidence is not completely convincing, it is remarkable that the Aquinas, already present in the legend about Albertus Magnus' automaton as a minor character, returns as a possible reader of a Hero's text.

Another work, entitled De inani et vacuo (About void), is both quoted without any reference to the author by the $14^{\text {th }}$-century philosopher Marsilius of Inghen in his Quaestiones super VIII physicorum libros (Questions on the Eight Books of the Physics; IV, 13), and copied in 1466 in a manuscript (Krakow, Biblioteka Jagiellonska, MS 568, ff. 207-211), where it is attributed to Hero. The Polish manuscript has two interesting issues:

- $\quad$ in the colophon the scribe's name of the antigraph is mentioned (quem inscripsit Landfridus); such a name (in the German version Lantfrid) is present also in the colophon of a Carolingian manuscript (München, Bayerische Staatsbibliothek, Clm. 14461, f.150) of religious content, copied in the 820s in Freising, and housed in St.Emmeram's abbey library, near Regensburg, at least since 1347. If the scribe would be the same, we would have an evidence of the connection between a Pneumatics tradition in Latin language and a Benedictine monastery, a place quite advanced from the technological point of view during the Middle Ages;

- the handwriting is very similar to Regiomontanus', the famous German astronomer and mathematician; in addition, we must say that the manuscript was bound in Germany, and the author of the letters included in the last part of the manuscript was a friend of Regiomontanus': Cristianus Roder de Hamburgo. Regiomontanus is said by the French humanist Pierre de la Ramée to have built an eagle, and a fly, that could fly away and back. Despite the fact that the story told by Pierre is certainly exaggerated, the fact that Regiomontanus may have dealt with an abridged version of Pneumatics, makes it less improbable.

Though there is no definitive proof of direct knowledge of Pneumatics during the Middle Ages, we, however, have 28 copies of Latin translations from Philo's or Hero's treatises made in the $14^{\text {th }}-15^{\text {th }}$ century. Based on a comparison of the incipits, they can be grouped into at very least 3 families:

- Quum/Cum apud antiquos: 12 manuscripts.

- Quoniam tuum, where the incipit mentioned above (In nomine Dei ...) is often, but not always, placed before: 15 manuscripts.

- $\quad$ Cum spirituale negocium: 1 manuscript.

A deep comparative study of all these manuscripts is in progress.

\subsubsection{A Useful Mechanical Automaton Called Maurizio}

Concerning craft tradition, we can remark that more or less in the same years one of the oldest mechanical automata appeared in Italy, in Orvieto. In 1347 the Opera del Duomo (Committee on the cathedral works) charged the clockmaker Francesco with building a clock mechanism, which required 285 pounds of iron, three blacksmiths, and eight craftsmen. The following year a bronze automaton was added to the clock as a striking system; it represents a "dottiere", a yard overseer, who was in charge of verifying compliance with working hours, and of forbidding workers to waste time. 
This is one of the rarest, and oldest, instances of automata (before the Renaissance), due inter alia to a virtually unknown clockmaker. In addition, this is clearly a device which was rather designed for practical purposes than to impress an audience: the automaton had become so familiar to the citizens of Orvieto, and to the yard workers, that it was even given a name: Maurizio (distortion of the word "muricçio", that indicates the yard).

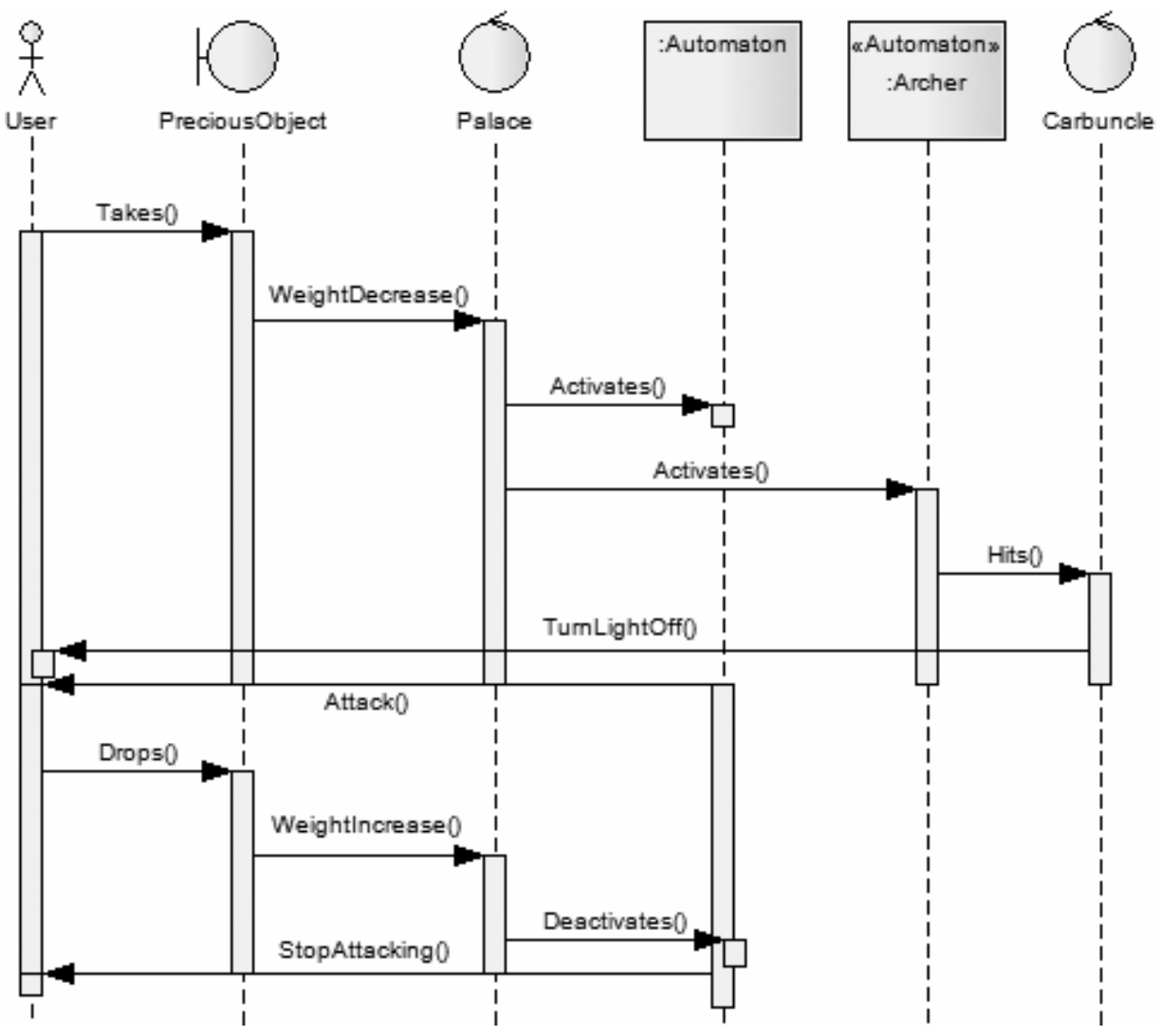

Fig. 1. UML sequence diagram of the episode of Gerbert d'Aurillac and Octavian's palace, from William of Malmesbury's biography

\section{Conclusions}

As it is clear from the above, the Medieval landscape is fragmented and often uncertain, and it must be frequently reconstructed upon secondary sources, such as literary texts, or hearsay. All sources and cross references need to be verified by means of careful philological and/or historical work.

In addition, such a thorough collection of sources would be useful only for documentary purposes, and would make it impossible to fully understand similarities and differences in implementation among automata designed in different ages. To solve this problem and not to reduce their works to a mere display of erudition, some 
scholars [16, 18, 35-37] have already attempted a classification of automata, based upon different features: their being connected with musical devices, rather than standalone; their being human figures rather than objects, or animals; the role they play in the story, as guardians, or entertainers; the finesse of their movements.

These classifications, though useful, cannot, however, fully capture the variety of behavior of automata in the same class, or any similarities in behavior among automata belonging to different classes. Consequently, it may be useful to introduce a different approach, based on a standard, language-independent representation of the automata's behavior.

To this purpose, at an advanced stage of sources' collection, it would be useful to make a modeling of the automata's behavior with UML diagrams; we believe that the diagram that can better represent the temporal sequence of actions and interaction between user and any automaton or system of automata is the sequence diagram. An example of this representation is given below, in relation to the above narrated episode of Gerbert d'Aurillac.

The next research step will therefore be to implement a database in which diagrams, similar to the above, will be added to quotations from the corresponding passages of literary and/or technical works, in order to allow abstraction and analysis of persistent archetypal elements, such as ideas and designs.

\section{References}

1. Schmidt, W., Nix, L.L.M., Schöne, H., Heiberg, J.L. (eds.): Heronis opera quae supersunt omnia. Teubner, Leipzig (1899)

2. Prager, F.D. (ed.): Philo of Byzantium, Pneumatica: the first treatise on experimental physics. Ludwig Reichert Verlag, Wiesbaden (1974)

3. Drachmann, A.G.: Ktesibios, Philon and Heron: A Study in Ancient Pneumatics, Munksgaard, Copenhagen (1948)

4. Hill, D.R.: The Book of Ingenious Devices: Kitáb al-Hiyal. By The Banú (sons of) Músà bin Shákir. Reidel Publishing Company, Dordrecht (1979)

5. Hill, D.R. (ed.): The Book of Knowledge of Ingenious Mechanical Devices by Ibn alRazzaz al-Jazari. Springer Science, Dordrecht (1974)

6. Reiske, J.J. (ed.): Constantini Porphyrogeniti Imperatoris De Ceremoniis Aulæ Byzantinæ. Weber, Bonn (1829)

7. Lewis, M.J.T.: Antique Engineering in the Byzantine World. In: Lavan, L., Zanini, E., Sarantis, A. (eds.) Technology in Transition A.D. 300-650, Brill, Leiden, pp. 367-378 (2007)

8. Ravegnani, G.: L'ambasceria di Liutprando di Cremona alla corte di Costantino Porfirogenito e il Libro delle cerimonie. In: SYNDESMOS, pp. 323-337. Università di Catania, Catania (1994)

9. Muratori, L.A. (ed.): Rerum Italicarum Scriptores, Ex typographia Petri Cajetani Viviani, Florentiae, vol. II, caput II, pp. 469-470 (1748)

10. Jacobsthal, P.: Ornamente Griechischer Vasen - Aufnahmen, Beschreibungen und Untersuchungen. Frankfurter Verlags-anstalt, Berlin (1927)

11. Briant, P.: Histoire de l'Empire perse. Librairie Artheme Fayard, Paris (1996)

12. Herodote: Histoires. Tome VII: Livre VII: Polymnie. Texte établi et traduit par Ph.-E. Legrand. Les Belles Lettres, Paris (1986)

13. Ruta, C. (ed.): Poeti arabi di Sicilia. Edi.bi.si, Messina (2009)

14. Trapp, E.: Learned and Vernacular Literature in Byzantium: Dichotomy or Symbiosis? Dumbarton Oaks Papers 47, 115-129 (1993) 
15. Mommsen, T., Traube, L. (eds.): Cassiodori senatoris Variae. apud Weidmannos, Berolini (1894)

16. Bruce, J.D.: Human Automata in Classical Tradition and Mediaeval Romance. Modern Philology 10, 511-526 (1913)

17. White Jr., L.T.: Medieval Engineering and the Sociology of Knowledge. The Pacific Historical Review 44, 1-21 (1975)

18. Truitt, E.R.: Trei poëte, sages dotors, qui mout sorent di nigromance: Knowledge and Automata in Twelfth-Century French Literature. Configurations: A Journal of Literature, Science, and Technology 12, 167 (2004)

19. Sharpe, J. (ed.): William of Malmesbury's Chronicle of the Kings of England. Henry G. Bohn, London (1847)

20. Migne, J.P. (ed.): William of Malmesbury De gestis regum Anglorum libri quinque. Patrologia cursus completes, Series Latina, Paris, vol. II, pp. 179-181 (1862)

21. Legrand, E.: Bibliothèque grecque vulgaire. Mainsonneuve, Paris (1880)

22. Miller, E.: Poème allégorique de Meliténiote. Notices et extraits des manuscrits de la bibliothèque impériale et autres bibliothèques 19, 1-138 (1858)

23. Flusche, A.M.: The Life and Legend of Gerbert of Aurillac: The Organbuilder Who Became Pope Sylvester II. Edwin Mellen Press, Lewiston (2006)

24. van Egmond, W.: Practical Mathematics in the Italian Renaissance: A catalogue of Italian Abbacus Manuscripts and Printed Books to 1600. Istituto e Museo di Storia della Scienza, Firenze (1981)

25. Ambrosetti, N.: L'eredità arabo-islamica nelle scienze e nelle arti del calcolo dell'Europa medievale. LED edizioni, Milano (2008)

26. Houben, H., von Sizilien II, R.: Herrscher zwischen Orient und Okzident. Wissenschaftliche Buchgesellschaft, Darmstadt (1997)

27. Setton, K.M.: The Byzantine Background to the Italian Renaissance. Proceedings of the American Philosophical Society 100, 1-76 (1956)

28. Rose, V.: Die Lücke im Diogenes Laertius und der alten Übersetzer. Hermes: Zeitschrift für klassische Philologie I, 373-385 (1866)

29. Birkenmajer, A.: Vermischte Untersuchungen zur Geschichte der mittelalterlichen Philosophie. Aschendorffschen, Munster (1922)

30. Haskins, C.H.: Further Notes on Sicilian Translations of the Twelfth Century. Harvard Studies in Classical Philology 23, 155-166 (1912)

31. Haskins, C.H.: Studies in the History of Medieval Science. Harvard University Press, Cambridge (1924)

32. Haskins, C.H.: The Sicilian Translators of the Twelfth Century and the First Latin Version of Ptolemy's Almagest. Harvard Studies in Classical Philology XXI, 75-102 (1910)

33. Birkenmajer, A.: La Bibliothèque de Richard de Fournival. In: d'Alverny, M.T. (ed.) Études d'histoire des sciences et de la philosophie au Moyen Age. Studia Copernicana, vol. 1, pp. 117-210. Zakład Narodowy im. Ossolińskich, Wrocław (1970)

34. Grant, E.: Henricus Aristippus, William of Moerbeke and Two Alleged Mediaeval Translations of Hero's Pneumatica. Speculum 46, 656-669 (1971)

35. Pugliara, M.: Il mirabile e l'artificio: creature animate e semoventi nel mito e nella tecnica degli antichi. L'erma di Bretschneider, Roma (2003)

36. Söhring, O.: Werke bildender Kunst in altfranzösischen Epen. Romanische Forschungen 12, 493-640 (1900)

37. Faral, E.: Le merveilleux et ses sources dans les descriptions des romans français du XIIe siècle. In: Faral, E. (ed.) Recherches sur les sources latines des contes et romans courtois du Moyen Age, Champion, Paris, pp. 307-388 (1913) 